\section{The Structures of German Mathematics Textbooks}

\author{
Sebastian Rezat, Giessen (Germany)
}

\begin{abstract}
From a socio-cultural perspective it is argued that the modality of artefacts has structuring effects on the activities in which the artefact is involved. The mathematics textbook is an artefact that has a major influence on the activity of learning mathematics. Against this setting, the structures of the units in German mathematics textbooks for different grades and ability levels have been analysed. Firstly, the different structural elements have been examined with regard to: characteristics in terms of content; linguistic characteristics; visual characteristics; their pedagogical functions within the learning process; and situative conditions. Secondly, the orders of the structural elements within the units of the different textbooks have been compared. The findings reveal that the structure of the units is very similar in different mathematics textbooks. The units are not only composed of analogous structural elements, but these elements are also arranged in almost the same sequence. In order to develop a deeper understanding of these findings the structure of the units has been compared to the influential learning theories of J. F. Herbart and H. Roth. On this basis it is argued that the structure of the units seems to reflect the phases of idealised learning processes in general. The issue is raised if this is an appropriate structure in order to provide opportunities to learn mathematics.
\end{abstract}

ZDM-Classification: U20

\section{Textbooks - A Socio-Cultural Perspective}

From a socio-cultural perspective the mathematics textbooks can be regarded as an artefact in the broad sense of the term. It is historically developed, culturally formed, produced for certain ends and used with particular intentions. On the one hand, mathematics textbooks can therefore be analysed with respect to their social and cultural imprint. They provide information about the activities that they are involved in. Thus, Dowling's 'Sociology of Mathematics Education' (1998) is based on the analysis of a school mathematics scheme.

On the other hand, the mathematics textbook is involved in the activities of teaching and learning mathematics. Within these activities the modalities of artefacts have structuring effects on their users (cf. Rabardel 2002). Whereas a number of studies have examined the role of ICT in terms of tool use (cf. Lerman 2006) the constraints that the modality of the mathematics textbook imposes on its users have not gained much attention. This becomes even more striking reading Howsons comment on the role of mathematics textbooks compared to that of ICT: "But despite the obvious powers of the new technology it must be accepted that its role in the vast majority of the world's classrooms pales into insignificance when compared with that of textbooks and other written materials.” (Howson 1995, p. 21)

In order to gain a deeper understanding of the modality of the mathematics textbooks a qualitative analysis of the structure of German mathematics textbooks is presented in this paper. Furthermore, the cultural imprint on the structures of German mathematics textbooks is revealed.

\section{The Analysis}

In their analysis of 418 mathematics and science textbooks from 48 different educational systems Valverde, et al. (2002) distinguish between two structural levels in textbooks: the macrostructure and the microstructure. According to their definition macrostructures refer to "structural features that cut across the entire book" (Valverde, et al. 2002, p. 21), whereas microstructures are "associated with specific lessons intended for use in a small number of classroom instructional sessions” (Valverde, et al. 2002, p. 21).

According to their terminology this paper focuses on the microstructures of German mathematics textbooks for lower and upper secondary level. A total number of 14 mathematics textbooks from the three major branches (Hauptschule, Realschule, Gymnasium) of the German tripartite school system have been analysed. Three major German textbook publishers (Cornelsen, Klett, Schroedel) have been asked for samples of their best-selling textbook series. With one exception (Lergenmüller, Schmidt 2002), one book of each publisher has been selected for each branch of lower secondary level. For upper secondary level two books have been selected from each publisher, one for lower achievers and one for higher achievers.

The data on the microstructures of the textbooks have been gathered from the initial pages of the mathematics textbooks that introduce the structure of the book to students. As a source for the analysis of the microstructures of mathematics textbooks these introductory pages were preferred to the units itself, because they do not only explain the general structure of the book, but also provide information about the author's intentions concerning that structure. Books that do not comprise these introductory pages were excluded from the analysis. This was especially the case for all the mathematics textbooks designed for the branch 'Hauptschule'.

Since there is no generally accepted terminology it is not possible to simply compare the microstructures of different textbooks directly. Both, the names of the structural elements and the terms that are used to characterize the structural elements differ in every textbook. Therefore, it was necessary to code the information about the structural elements in order to be able to compare the microstructures of different mathematics textbooks. In a first step, categories have 
been generated inductively by means of qualitative content analysis according to Mayring (2000, 2003). A description of one structural element has been defined as the unit of analysis. Each of these descriptions has been explored in terms of more abstract categories subsuming all the different characteristics mentioned. For example, in the following description characteristics of four different categories are mentioned.

"Im Kasten wird das Merkwissen zusammengefasst dargestellt. In der knappen Formulierung dient es wie ein Lexikon zum Nachschlagen“ (Maroska, et al. 2004, p. 6)

(The kernels are summarized in a box. Because of the concise wording it can be used like a reference book to look up things. [Translation: SR])

These are:

1. a visual characteristic: the box

2. a characteristic in terms of content: kernels

3. a linguistic characteristic: concise wording

4. an expected utilization: to look up things

The object of working through the material was to generate a system of well-defined categories by means of constant revision and refinement.

In a second step, the descriptions of the structural elements were coded according to these categories. Each characteristic of a structural element was coded and assigned to one particular category. On the basis of the coded descriptions a comparison of the structural elements of different textbooks has been enabled. Similar structural elements in different textbooks were identified by comparing their categorized and coded descriptions.

Finally, the sequences of the structural elements in the different textbooks were compared. The required data concerning the order of the structural elements within the units of the textbooks was also collected from the introductory pages.

\section{Results}

By means of qualitative content analysis of the introductory pages the following categories describing the elements on a micro structural level of mathematics textbooks were generated:

- characteristics in terms of content

- linguistic characteristics

- visual characteristics

- $\quad$ pedagogical functions

- $\quad$ situative conditions

The term 'pedagogical functions' refers to functions like 'engaging the student actively', 'informing', 'practising', etc. The notion of situative conditions is twofold. It comprises expected activities as well as suggested contexts of use such as the introduction of new subject matter or homework.

As aforementioned, the structural elements on the microstructural level of different mathematics textbooks have been coded on the basis of these five categories. Comparing the structural elements of different mathematics textbook reveals that most of the microstructures of German mathematics textbooks comprise the following five elements:

- $\quad$ introductory tasks

- exposition $^{1}$

- kernels $^{2}$

- $\quad$ worked examples

- $\quad$ exercises

Some textbooks also offer review exercises.

A compilation of the characteristics of these five elements is given in Tab. 1. It summarizes the results of the coding process that was described in the previous section.

Furthermore, the sequences of the five elements are almost identical in most of the analysed textbooks.

The results of the comparison of the microstructures of German mathematics textbooks are summarized in Tab. 2. In this table similar elements appear in the same column and the order of the elements within the microstructure is maintained in the lines.

1 The characteristics of this element correspond to the notion of 'exposition' as described by Love and Pimm (1996). Therefore the term was adopted.

2 The characteristics of this element correspond to the notion of 'kernels' as described by van Dormolen (1986).

Therefore the term was adopted. 
Tab. 1: Characteristics of the structural elements in German mathematics textbooks

\begin{tabular}{|c|c|c|c|c|c|}
\hline characteristic & introductory tasks & exposition & kernels & worked examples & $\begin{array}{l}\text { exercises and } \\
\text { problems }\end{array}$ \\
\hline $\begin{array}{l}\text { characteristics in } \\
\text { terms of content }\end{array}$ & situations & $\begin{array}{l}\text { new material, } \\
\text { procedures, } \\
\text { theorems, } \\
\text { definitions } \\
\end{array}$ & $\begin{array}{l}\text { results, } \\
\text { definitions, } \\
\text { theorems }\end{array}$ & $\begin{array}{l}\text { details the execution } \\
\text { of a particular } \\
\text { algorithm or solution } \\
\text { strategy }\end{array}$ & $\begin{array}{l}\text { routine tasks; } \\
\text { differentiated tasks; } \\
\text { open tasks; } \\
\text { applications; problems }\end{array}$ \\
\hline $\begin{array}{l}\text { liguistical } \\
\text { characteristics }\end{array}$ & & $\begin{array}{l}\text { language that is } \\
\text { appropriate for } \\
\text { students and for } \\
\text { their age group }\end{array}$ & concise & & \\
\hline $\begin{array}{l}\text { visiual } \\
\text { characteristics }\end{array}$ & & & $\begin{array}{l}\text { boxed, clearly } \\
\text { structured }\end{array}$ & somehow highlighted & $\begin{array}{l}\text { distinct markings } \\
\text { indicate different } \\
\text { ability levels } \\
\end{array}$ \\
\hline $\begin{array}{l}\text { pedagogical } \\
\text { characteristics }\end{array}$ & $\begin{array}{l}\text { Engage the student } \\
\text { actively; recalling relevant } \\
\text { past ideas; preparatory to } \\
\text { the new material; } \\
\text { assistance in order to } \\
\text { approach the new material }\end{array}$ & $\begin{array}{l}\text { explanatory, } \\
\text { development of } \\
\text { new ideas, } \\
\text { introduction of } \\
\text { new concepts }\end{array}$ & $\begin{array}{l}\text { overview, } \\
\text { consolidation }\end{array}$ & paradigmatic & $\begin{array}{l}\text { engage the student } \\
\text { actively; consolidation, } \\
\text { provide opportunities } \\
\text { to practice and acquire } \\
\text { particular skills }\end{array}$ \\
\hline $\begin{array}{l}\text { situative } \\
\text { conditions }\end{array}$ & $\begin{array}{l}\text { lesson, students try, puzzle } \\
\text { and discover on their own }\end{array}$ & & $\begin{array}{l}\text { also for private } \\
\text { study; to be } \\
\text { used like a } \\
\text { reference book }\end{array}$ & $\begin{array}{l}\text { consulted by students } \\
\text { who need assistance } \\
\text { to do the exercise }\end{array}$ & \\
\hline
\end{tabular}

Tab. 2: The microstructures of German mathematics textbooks

\begin{tabular}{|c|c|c|c|c|c|c|c|c|c|}
\hline textbook & \multicolumn{9}{|c|}{ microstructure } \\
\hline $\begin{array}{l}\text { Lambacher } \\
\text { Schweizer } \\
\text { Analysis } \\
\text { (Buck, et al. } \\
\text { 2000, 2002) }\end{array}$ & & $\begin{array}{l}\text { introductory } \\
\text { tasks }\end{array}$ & & exposition & & kernels & $\begin{array}{c}\text { worked } \\
\text { examples }\end{array}$ & exercises & \\
\hline $\begin{array}{l}\text { Mathematik } \\
\text { Analysis } \\
\text { (Jahnke, Wuttke } \\
\text { 2001) }\end{array}$ & & $\begin{array}{l}\text { introductory } \\
\text { tasks }\end{array}$ & & & & kernels & & exercises & \\
\hline \multirow{3}{*}{$\begin{array}{l}\text { Mathematik - } \\
\text { Neue Wege } \\
\text { (Lergenmüller, } \\
\text { Schmidt 2002) }\end{array}$} & \multirow{3}{*}{$\begin{array}{l}\text { advance } \\
\text { organizer }\end{array}$} & \multirow{3}{*}{$\begin{array}{l}\text { introductory } \\
\text { tasks }\end{array}$} & & & & \multirow{3}{*}{ kernels } & \multirow{3}{*}{$\begin{array}{c}\text { worked } \\
\text { examples }\end{array}$} & $\begin{array}{c}\text { verification } \\
\text { devices }\end{array}$ & \multirow{3}{*}{$\begin{array}{c}\text { review } \\
\text { exercises }\end{array}$} \\
\hline & & & & & & & & hints & \\
\hline & & & & & & & & exercises & \\
\hline \multirow{3}{*}{$\begin{array}{l}\text { Elemente der } \\
\text { Mathematik } \\
\text { (Griesel, et al. } \\
\text { 2004) }\end{array}$} & & \multirow{3}{*}{$\begin{array}{c}\text { task + } \\
\text { solution }\end{array}$} & \multirow{3}{*}{$\begin{array}{c}\text { tasks for } \\
\text { consolidation }\end{array}$} & \multirow{3}{*}{ exposition } & & \multirow{3}{*}{ kernels } & & $\begin{array}{l}\text { verification } \\
\text { devices }\end{array}$ & \\
\hline & & & & & & & & $\begin{array}{c}\text { worked } \\
\text { examples }\end{array}$ & \\
\hline & & & & & & & & exercises & \\
\hline $\begin{array}{l}\text { Mathematik } \\
\text { plus } \\
\text { (Pohlmann, } \\
\text { Stoye 2001) }\end{array}$ & & $\begin{array}{l}\text { introductory } \\
\text { tasks }\end{array}$ & & & $\begin{array}{c}\text { worked } \\
\text { examples }\end{array}$ & kernels & & exercises & $\begin{array}{l}\text { review } \\
\text { exercises }\end{array}$ \\
\hline $\begin{array}{l}\text { Schnittpunkt } \\
\text { (Maroska, et al. } \\
\text { 2004) }\end{array}$ & & $\begin{array}{l}\text { introductory } \\
\text { tasks }\end{array}$ & & exposition & & kernels & $\begin{array}{c}\text { worked } \\
\text { examples }\end{array}$ & exercises & \\
\hline $\begin{array}{l}\text { Mathematik } \\
\text { heute } \\
\text { (Griesel, et al. } \\
\text { 2002) }\end{array}$ & & $\begin{array}{c}\text { task + } \\
\text { solution }\end{array}$ & $\begin{array}{c}\text { tasks for } \\
\text { consolidation }\end{array}$ & exposition & & kernels & $\begin{array}{c}\text { worked } \\
\text { examples }\end{array}$ & exercises & \\
\hline $\begin{array}{l}\text { Mathematik } \\
\text { Real } \\
\text { (Koullen 2004) }\end{array}$ & & situation & & & & kernels & $\begin{array}{c}\text { worked } \\
\text { examples }\end{array}$ & exercises & \\
\hline
\end{tabular}


Tab. 2 shows that Howson's conclusion regarding the structure of mathematics textbooks from 8 different countries ${ }^{3}$ might be applied to the German case: "There is a great similarity in the way mathematics is presented" (Howson 1995, p. 38).

Solely the structures of the books 'Mathematik heute' and 'Elemente der Mathematik' published by Schroedel differ from the others. At the beginning of a lesson the two books expose a task with a worked out solution. This solution is worked out much more in detail than the worked examples that are presented in other textbooks in connection with the kernels. Just as the introductory tasks in other textbooks, the tasks with worked out solutions are supposed to engage the student actively and lead him to the kernels. After the task with worked out solution the microstructures of the two books incorporate tasks for consolidation. These tasks provide an opportunity to work over the new material.

The books that were excluded from the analysis for lack of pages explaining the structure of the book, can now be examined with the help of the obtained framework. The microstructure of Lambacher Schweizer (Schmid, Weidig 2002) coincides with the structure of the framework. The three books that are designed for the branch 'Hauptschule' - Lernstufen Mathematik (Leppig 2001), Einblicke Mathematik (Becherer 2001), Maßstab (Schröder, et al. 2003) - basically reflect the structure of the framework. In contrast to the other books, the initial part is not a task but an introductory situation that is described.

\section{A socio-cultural analysis of the microstructures of German mathematics textbooks}

The similitude of the microstructures of German mathematics textbooks is in need of explanation. What are the origins of this correspondence? To answer this question the following investigation will focus on the pedagogical functions of the structural elements.

From all characteristics of the elements the pedagogical functions seem to be vitally important because of three reasons:

1. The authors seem to attach great importance to the pedagogical functions in their descriptions of the elements. The quantity of pedagogical functions that are mentioned outnumbers all the other characteristics.

2. Most of the German names the authors use to label the structural elements refer to pedagogical functions.

3. The pedagogical functions determine the flow of the units in mathematics textbooks (cf. Klingberg 1972).

In order to develop a deeper understanding of the microstructures in German mathematics textbooks the didactical flow, i.e. the progression of pedagogical functions within a lesson, will be compared to two of the

\footnotetext{
3 England, France, Japan, The Netherlands, Norway, Spain,
} Switzerland, U.S.A. most influential German theories of instruction - J. F. Herbart's formal theory of instruction and H. Roth's model of the learning process.

Herbart's "five" formal steps of instruction may be summarized as follows (cf. Rein, et al. 1903) ${ }^{4}$ : (H0) objective - engaging the student actively;

(H1) preparation - a process of recalling relevant past ideas or memories in order to relate new material to be learned;

(H2) presentation - presenting new material by means of concrete objects or actual experience;

(H3) association - thorough assimilation of the new idea through comparison with former ideas and consideration of their similarities and differences in order to implant the new idea in the mind;

(H4) generalization - the process of conceptualising the new idea and subsuming it into the body of previously acquired knowledge

(H5) application of the newly acquired knowledge

Roth's model of the learning process has the following structure (cf. Roth 1983):

(R1) motivation - a problem is posed and the learning process commences

(R2) difficulties - the student encounters difficulties in solving the problem

(R3) solution - the solution is found or provided by the teacher

(R4) execution - the new procedure or strategy is performed by the student

(R5) memorizing and practising - the new procedure is memorized and practised.

(R6) integration - using acquired knowledge not in a purely utilitarian way, but so that every learned idea becomes a part of the functional mind and an aid to a clear, vital interpretation of life.

Herbart's theory of instruction is characterized by the idea of apperception and generalization. This becomes apparent in steps (H1), (H3) and (H4). This idea of subsuming new knowledge in a pre-existent body of knowledge is not evident in Roth's theory. On the contrary, he emphasises a phase of resistance that the student encounters in dealing with a new and yet unknown problem. This is obvious in step (R2).

Despite these pivotal differences some crucial ideas are analogous in the two theories. Both of them start with a phase of motivation that has to precede the whole process and end with the application of the acquired knowledge. Furthermore, a phase of presenting new material is intrinsic to both of them.

Comparing the microstructures of German mathematics textbooks to the theories by Herbart and Roth reveals that the characteristics of most of the structural elements in the textbooks correspond to the ideas behind particular

\footnotetext{
4 The theory that is referred to as 'Herbart's theory' in this paper is in fact an interpretation of Herbart's theory that was elaborated by Herbart's followers W. Rein, A. Pickel, and E. Scheller.
} 
steps in the two theories. The framework of a unit in a German mathematics textbook seems to implement basically the structure of Herbart's theory.

In good Herbartian fashion the introductory tasks are characterized by propaedeutic functions. The recall of relevant past ideas, motivational aspects and the idea of engaging the student actively are key features of both, 'introductory tasks' and Herbart's steps (H0) and (H1) respectively. Herbart also points out that a task might be the appropriate means in order to achieve these objectives.

If the introductory tasks are followed by the exposition of the new material this corresponds to the idea of Herbart's step (H2) 'presentation'.

The kernels in mathematics textbooks comprise fundamental results, definitions and theorems. Since mathematics is usually handed down as a deductive theory, definitions and theorems inevitably relate new material to past ideas and thereby conceptualise new ideas. Further characteristics of kernels are their clarity and their conciseness. All these characteristics match Herbart's steps (H3) and (H4). According to Herbart, step (H4) concludes with paradigmatic and generic examples. Likewise, in mathematics textbooks, the kernels are most commonly followed by worked examples.

Finally, just as postulated by Herbart, the lessons in mathematics textbooks end with the application of the newly acquired knowledge.

This comparison reveals that the framework of the microstructures in German mathematics textbooks follows the structure of Herbart's theory. Despite the steps that are comparable in both theories, the microstructures of German mathematics textbook do not seem to incorporate specific aspects that are fundamental to the theory by Roth. Especially, there is no reference to the heart of Roth's theory, i.e. steps (R2), (R3), and (R4).

As pointed out before, the microstructures of the two books 'Mathematik heute' and 'Elemente der Mathematik' published by Schroedel differ from the framework. In both cases the units start out with a task and its worked out solution, followed by tasks for consolidation. However, this structure seems to reflect the heart of Roth's theory. As suggested by Roth, a task constitutes the starting point of the lesson. By providing a detailed solution immediately it seems to be anticipated that the student encounters difficulties in solving the task on his own. Thus, the lesson moves on to step (R3), i.e. the solution of the task. This is followed by exercises for consolidation in order to ensure that the student performs the new procedure or strategy. The lesson proceeds with supplementary material and kernels in a Herbartian manner.

Consequently the structures of these two books published by Schroedel incorporate fundamental aspects of both theories.

\section{Conclusion}

On the one hand the preceding analysis revealed the great similarity of the microstructures of German mathematics textbooks. On the other hand it provides evidence that these structures correspond to theories of learning by J. F. Herbart and $\mathrm{H}$. Roth respectively. This correspondence is not necessarily a matter of conscious imitation, but might be explained as an expression of cultural heritage or world knowledge. As Meyer (1987) points out, generations of German teachers were educated following the Herbartian tradition and thus the terminology that was formed by Herbart's followers is still in use, although it is scarcely remembered that it goes back to Herbart and his followers.

However, the theories by Herbart and Roth are models of processes. One fundamental aspect of a process is its temporal dimension. In a book the temporal dimension is transformed into a spatial arrangement. The temporal order of the phases of the process is translated into a spatial sequence of different structural elements. As a consequence, the units of mathematics textbooks might be labelled 'frozen lessons'.

The pivotal difference is that a temporal sequence is linear. The course of its phases cannot be changed. Whereas it is possible to change the sequence, or to skip parts, in a spatial arrangement. For example, Hacker (1980) as well as Love and Pimm (1996) describe, that students are often impatient with the introductory tasks or the exposition and skip to the kernels. As a consequence the flow of the lessons is changed and the lessons in textbooks might not be used as intended by the authors.

This raises the issue if a structure that relates to learning theories is an appropriate model for the microstructures of mathematics textbooks. Does this structure suit the way students utilize their mathematics textbooks? Do students read entire units and thus follow the flow of the 'lessons'? Are there microstructures that are more appropriate for the students' needs?

Since the utilization of mathematics textbooks by students has scarcely been investigated these questions cannot be answered so far. But, the impression arises that the so-called 'student's book' - as it is labelled by the publishers - is in fact a 'teacher's book', because it is the teacher who can transform a spatial arrangement back into a temporal sequence. And in fact, several studies have shown that this is a common way for teachers to utilize mathematics textbooks in order to prepare their lessons (cf. Bromme, Hömberg 1981, Hopf 1980, Stodolsky 1989, Valverde, et al. 2002, Woodward, Elliott 1990). 


\section{References}

Becherer, J. (2001): Einblicke Mathematik 8. Hauptschule, Rheinland-Pfalz. - Stuttgart: Ernst Klett

Bromme, R., Hömberg, E. (1981): Die andere Hälfte des Arbeitstages - Interviews mit Mathematiklehrern über alltägliche Unterrichtsvorbereitung. - Bielefeld: Institut für Didaktik der Mathematik der Universität Bielefeld (Materialien und Studien; 25)

Buck, H., Dürr, R., Freudigmann, H., Reinelt, G., Zinser, M. (2000): Lambacher Schweizer Analysis. Grundkurs, Gymnasium, Hessen, Niedersachsen, Bremen, Hamburg, Schleswig-Holstein, Rheinland-Pfalz und Saarland. Stuttgart: Ernst Klett

Buck, H., Dürr, R., Freudigmann, H., Reinelt, G., Zinser, M. (2002): Lambacher Schweizer Analysis. Leistungskurs, Gymnasium, Nordrhein-Westfalen. - Stuttgart: Ernst Klett

Dormolen, J. v. (1986): Textual Analysis. - In: Christiansen, B., Howson, A. G. and Otte, M. (Eds.), Perspectives on Mathematics Education. Dordrecht: Reidel (Mathematics Education Library), p. 141-171

Dowling, P. (1998): The Sociology of Mathematics Education. Mathematical Myths / Pedagogic Texts. - London: The Falmer Press (Studies in Mathematics Education Series; 7)

Griesel, H., Postel, H., Hofe, R. v. (Eds.) (2002): Mathematik heute 8. Realschule, Hessen. - Hannover: Schroedel

Griesel, H., Postel, H., Suhr, F. (Eds.) (2004): Elemente der Mathematik 8. - Hannover: Schroedel

Hacker, H. (1980): Didaktische Funktionen des Mediums Schulbuch. - In: Hacker, H. (Ed.) Das Schulbuch. Funktion und Verwendung im Unterricht. Bad Heilbrunn: Klinkhardt (Studientexte zur Grundschuldidaktik), p. 7-30

Hopf, D. (1980): Mathematikunterricht. Eine empirische Untersuchung zur Didaktik und Unterrichtsmethode in der 7. Klasse des Gymnasiums. - Stuttgart: Klett-Cotta (Veröffentlichungen aus dem Projekt Schulleistung; 4)

Howson, G. (1995): Mathematics Textbooks: A Comparative Study of Grade 8 Texts. - Vancouver: Pacific Educational Press (TIMSS Monograph; 3)

Jahnke, T., Wuttke, H. (Eds.) (2001): Mathematik Analysis. Berlin: Cornelsen

Klingberg, L. (1972): Einführung in die Allgemeine Didaktik. Berlin: Volk und Wissen

Koullen, R. (Ed.) (2004): Mathematik Real 8. Realschule, Nordrhein-Westfalen. - Berlin: Cornelsen

Leppig, M. (Ed.) (2001): Lernstufen Mathematik 8. Hauptschule, Nordrhein-Westfalen. - Berlin: Cornelsen

Lergenmüller, A., Schmidt, G. (Eds.) (2002): Mathematik - Neue Wege 8. Gymnasium. - Hannover: Schroedel

Lerman, S. (2006): Socio-Cultural Research in PME. - In: Gutiérrez, A. and Boero, P. (Eds.), Handbook of Research on the Psychology of Mathematics Education. - Rotterdam: Sense Publishers, p. 347-366

Love, E., Pimm, D. (1996): 'This is so': a text on texts. - In: Bishop, A. J., Clements, K., Keitel, C., Kilpatrick, J. and Laborde, C. (Eds.), International Handbook of Mathematics Education. Vol. 1. Dordrecht: Kluwer, p. 371-409

Maroska, R., Olpp, A., Stöckle, C., Wellstein, H. (2004): Schnittpunkt 8. - Stuttgart: Ernst Klett

Mayring, P. (2000): Qualitative Content Analysis. - In: Forum Qualitative Sozialforschung / Forum: Qualitative Social Research [On-line Journal] 1(2), http://www.qualitativeresearch.net/fqs-texte/2-00/2-00mayring-e.htm (Date of access: 19.09.2006)

Mayring, P. (2003): Qualitative Inhaltsanalyse. - Weinheim, Basel: Beltz

Meyer, H. (1987): Unterrichtsmethoden. Bd. 1. - Frankfurt a. M.: Cornelsen Scriptor

Pohlmann, D., Stoye, W. (Eds.) (2001): Mathematik plus 8.
Gymnasium, Nordrhein-Westfalen. - Berlin: Volk und Wissen

Rabardel, P. (2002): People and Technology: a cognitive aproach to contemporary instruments.

http://ergoserv.psy.univ-

paris8.fr/Site/ShowArticle.asp?NumArt=99\&Act_Group=1 http://ergoserv.psy.univ-

paris8.fr/Site/ShowArticle.asp?NumArt=100\&Act_Group=1 (Date of access: 28.07.2005)

Rein, W., Pickel, A., Scheller, E. (1903): Theorie und Praxis des Volksschulunterrichts nach Herbartischen Grundsätzen. Das erste Schuljahr. - Leipzig: Verlag von Heinrich Bredt

Roth, H. (1983): Pädagogische Psychologie des Lehrens und Lernens. - Hannover: Schroedel

Schmid, A., Weidig, I. (Eds.) (2002): Lambacher Schweizer 8. Gymnasium, Nordrhein-Westfalen. - Stuttgart: Ernst Klett

Schröder, M., Wurl, B., Wynands, A. (Eds.) (2003): Maßstab 8. - Hannover: Schroedel

Stodolsky, S. S. (1989): Is Teaching Really by the Book? - In: Jackson, P. W. and Haroutunian-Gordon (Eds.), From Socrates to Software: The Teacher as Text and the Text as Teacher. Chicago: University of Chicago Press (Yearbook of the National Society for the Study of Education; 1), p. 159184

Valverde, G. A., Bianchi, L. J., Wolfe, R. G., Schmidt, W. H., Houang, R. T. (2002): According to the Book - Using TIMSS to investigate the translation of policy into practice through the world of textbooks. - Dordrecht: Kluwer

Woodward, A., Elliott, D. L. (1990): Textbook Use and Teacher Professionalism. - In: Elliott, D. L. and Woodward, A. (Eds.), Textbooks an Schooling in the United States. Chicago: The University of Chicago Press (Yearbook of the National Society for the Study of Education; 1), p. 178-193

\section{Author}

Rezat, Sebastian, Institut für Didaktik der Mathematik, Justus-LiebigUniversität Gießen, Karl-Glöckner-Str. 21c, D-35394 Gießen. E-mail: sebastian.rezat@math.uni-giessen.de 